\title{
DENTAL ANOMALY IN A MIDDLE MIOCENE FOSSIL OF THE GENUS SPERMOPHILINUS (RODENTIA, SCIURIDAE) FROM SOUTHERN GERMANY
}

\author{
JÉRÔME PRIETO', MICHAEL RUMMEL², PABLO PELÁEZ-CAMPOMANES, DAVIT VASILYAN ${ }^{4,5, *}$ \\ ' Department of Earth- and Environmental Science, Palaeontology \& Geobiology, Ludwig-Maximilians-University Munich, Richard- \\ Wagner-Str. 10,80333 Munich, Germany; e-mail: j.prieto@web.de. \\ 2 Naturmuseum der Stadt Augsburg, Ludwigstraße 14, 86152 Augsburg, Germany; e-mail: michael.rummel@augsburg.de. \\ ${ }_{3}^{3}$ Museo Nacional de Ciencias Naturales, MNCN-CSIC, C/ José Gutiérrez Abascal, 2, 28006 Madrid, Spain. \\ ${ }^{4}$ JURASSICA Museum, Route de Fontenais 21, 2900 Porrentruy, Switzerland; e-mail: davit.vasilyan@jurassica.ch. \\ ${ }^{5}$ Department of Geosciences, University of Fribourg, Chemin du musée 6, 1700 Fribourg, Switzerland. \\ * corresponding author
}

Prieto, J., Rummel, M., Peláez-Campomanes, P., Vasilyan, D. (2020): Dental anomaly in a middle Miocene fossil of the genus Spermophilinus (Rodentia, Sciuridae) from southern Germany. - Fossil Imprint, 76(1): 174-180, Praha. ISSN 2533-4050 (print), ISSN 2533-4069 (on-line).

\begin{abstract}
The maxillary presented in this work has been excavated in the middle Miocene karst filling Petersbuch 136 (Germany, Bavaria) and shows the oldest evidence of dental anomaly in a sciurid. The aberrant morphology, probably hyperdontia or no replacement of roots of deciduous teeth, affects the area of the P3, a tooth that is generally not well documented in the Spermophilinus record.
\end{abstract}

Key words: Bavaria, Miocene, Frankonian Jura, squirrel, tooth anomaly, P3

Received: November 27, 2019 | Accepted: March 31, 2020 | Issued: November 9, 2020

\section{Introduction}

Dental anomalies are recorded in almost all mammalian groups (Miles and Grigson 2003). These can affect the dentition in different ways, sometimes very spectacularly, as for instance: addition/absence of check teeth (hyperdontia/hypo(oligo- or ano-)dontia), reduction/enlargement of tooth size (micro-/macrodontia), incomplete formation (germination), fusion of two teeth (connation) and sharp bend of the root (dilaceration). Following Miles and Grigson (2003), rodents present supernumerary teeth (incisors, premolars and molars), retention of deciduous teeth, rarely absence of teeth, variation in the position and number of roots, connation of molars, rarely variation in tooth position, overgrowth of teeth (incisors, or even molars; see Jehon et al. 2015, Imai et al. 2018), while Charles and Viriot (2015) document aberrations in the shape of teeth.

The detection of these dental deviations requires the study of an extensive collection of specimens. This is difficult for investigation on fossils, where the number of studied specimens is generally limited and very fragmentary. A notable exception may be found in karstic fillings where very large bone accumulations can be found. This is the case in Petersbuch (southern Germany), where, during summer 2018, an especially rich fossiliferous fissure, Petersbuch 136, was discovered. The fauna contains a large number of well-preserved specimens of the Miocene sciurid Spermophilinus. One of these fossils, a maxillary, has an anomaly in the anterior part of the (pre)molar row, actually in the P3, a normally small rounded tooth which is even absent in some genera of the family. This rare specimen is presented in this paper.

\section{Material and methods}

The studied specimens from Petersbuch 136 are stored in the Naturmuseum Augsburg under accession numbers NMA-2019-1/2352 and NMA-2019-2/2352. The method used to measure the teeth follows that of Prieto et al. (2017: fig.1). The nomenclature of the morphologic elements of the teeth is in agreement with Casanovas-Vilar et al. (2015).

\section{D model}

The $\mu \mathrm{CT}$ scanning of the material is performed using Bruker Skyscan 2211, at the University of Fribourg, Switzerland. It was CT-scanned with a beam energy of $103 \mathrm{kV}$ and a flux of $115 \mu \mathrm{A}$ at a detector resolution of $17 \mu \mathrm{m}$ 
per pixel using a copper filter. The 3D model of the upper jaw has been generated by 3D visualisation software Amira 6.0 (FEI), at the JURASSICA Museum Porrentruy, Switzerland.

\section{The locality and its dating}

The karstic system of the White Jura- $\delta$ of Petersbuch near Eichstätt is well known due to its enrichment by Cenozoic fossils. More than 130 faunas (Oligocene to Pleistocene) have been discovered during the exploitation of the White Jura- $\delta$ quarries in the vicinity of the village Petersbuch near Eichstätt (Frankonian Alb, South Germany).

The fossil was collected from the fissure filling Petersbuch 136 in 2018. Thought the study of this new fauna is at an early stage, a relatively precise age of the fauna can be suggested based exclusively on a biostratigraphic methods and refers to the local scale proposed by Prieto and Rummel (2016; working hypothesis). The presence of many Cricetodontini at an evolutionary level close to that recorded in Petersbuch 68, with addition of the presence of Galerix exilis and Amphiperatherium, allows us to consider an age of the fissure between $\sim 14.5$ and $\sim 14$ Ma as very plausible.

\section{Abbreviations}

D upper deciduous tooth

Di diameter of the rounded tooth crown (for P3 only)

$\mathrm{H} \quad$ height of the tooth crown (for P3 only)

L length

M upper molar

MNCN Museo Nacional de Ciencias Naturales, Madrid, Spain

NMA Naturmuseum Augsburg, Augsburg, Germany

$\mathrm{P} / \mathrm{p} \quad$ upper/lower premolar

W width

\section{Systematic palaeontology}

\section{Order Rodentia Bowdich, 1821 \\ Family Sciuridae FISCHER, 1817}

\section{Genus Spermophilinus de BRUIJN et MeIn, 1968}

Type species. Sciurus bredai VON MEYER, 1848.

Comments. We still recognize Spermophilinus as valid genus and follow thus the point of view of de Bruijn and Bosma (2012 versus Kretzoi and Fejfar (2005); see details in Prieto et al. (2017)).
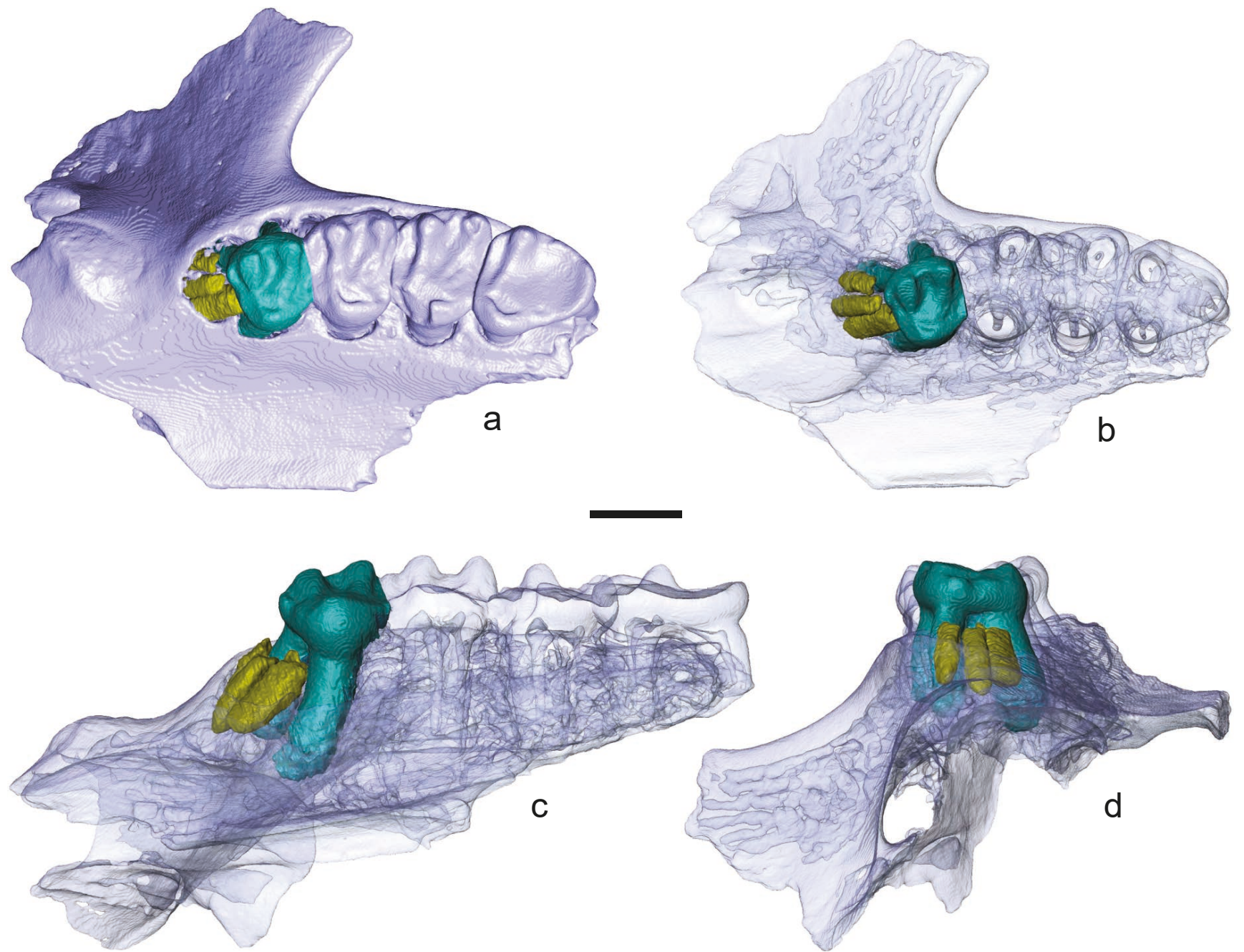

Text-fig. 1. Spermophilinus bredai (von Meyer, 1848): 3D models of a right upper jaw with (abnormal) P3, P4 and all molars (mirrored; NMA-2019-1/2352). a - the specimen in occlusal view showing the relative position of the three roots in place of P3 (yellow) compared to P4 (green); b - same view, with focus on P3-P4; c - lingual view; d - mesial view. Scale bars 2 mm. 


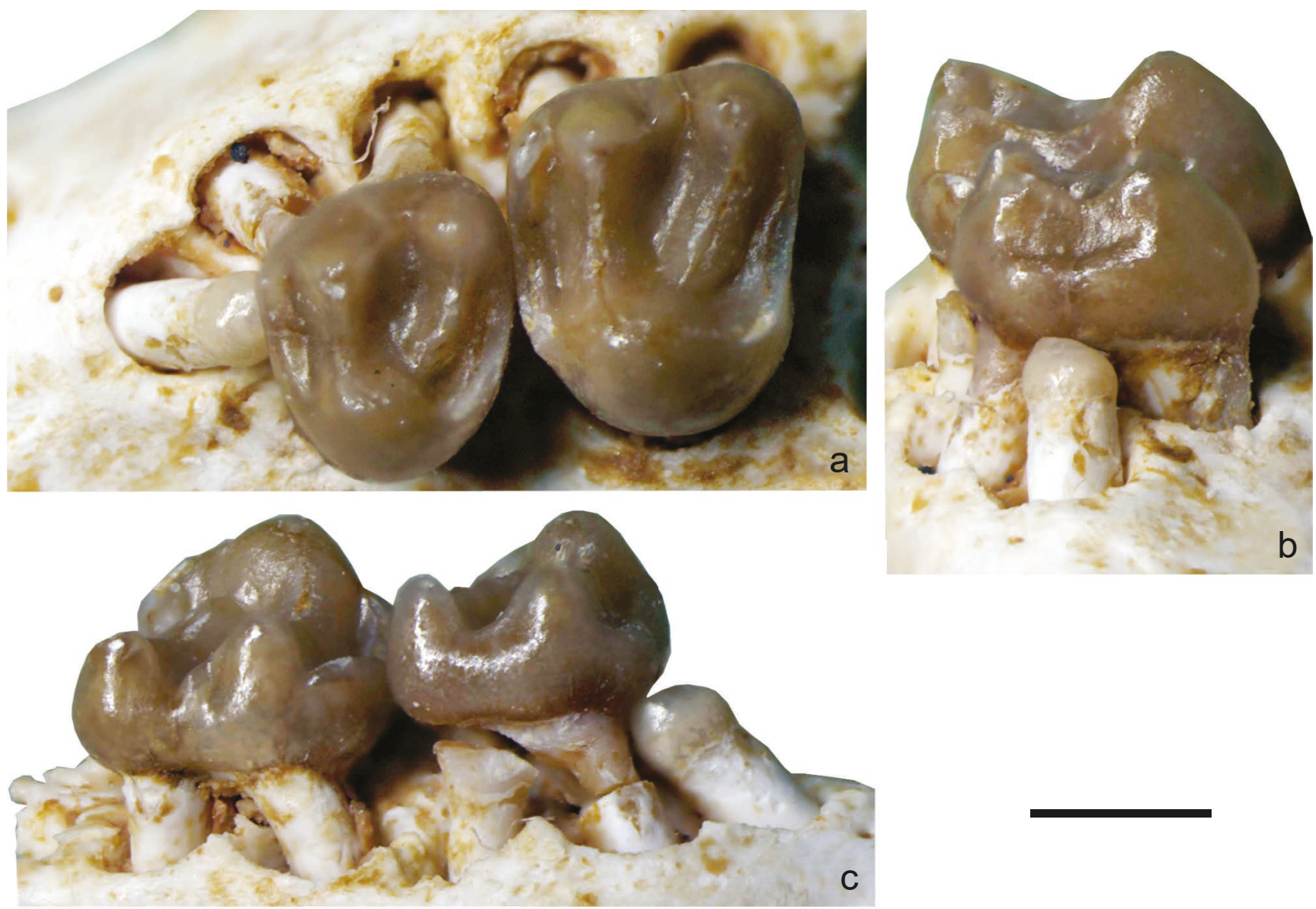

Text-fig. 2. Spermophilinus bredai (von MEYER, 1848): left upper jaw with P3-M1 (NMA-2019-2/2352). a - the specimen in occlusal view; $b$ - mesial view; c - labial view. Scale bars 1 mm.

\section{Spermophilinus bredai (von MEYER, 1848)}

Text-figs 1,2

Material and measurements. Right upper jaw with (abnormal) P3, P4 and all molars (NMA-20191/2352; Text-fig. 1). Measurements $(\mathrm{L} \times \mathrm{W}$ in $\mathrm{mm})$ : P4: 1.38 $\times 1.74 ; \mathrm{M} 1: 1.64 \times 2.06 ; \mathrm{M} 2: 1.71 \times 2.13 ; \mathrm{M} 3: 2.08 \times 2.05$.

Comparative material. Left upper jaw with P3-M1 from the same locality (NMA-2019-2/2352; Textfig. 2). Measurements: P3: Di: 0.54, H: 0.38; P4: $1.44 \times$ 1.65; M1: $1.68 \times 2.05$.

De s c ription. NMA-2019-1/2352. The fragmentary maxilla conserves the P3-M3 in situ. The specimen is adult as shown by the wear stage of the teeth. The $\mathrm{P} 3$ is not recognizable as such. The crown of the tooth or teeth is/are broken. This break reflects the original condition of the specimen and does not result from damage due to, for example, screen washing of the fossil-enriched sediment. Two posteriorly-directed roots are developed in front of the P4, between the two anterior roots of the last premolar. A very small third root emerges in front of the anterolabial root of the P4. The lingual root is the strongest. The morphology of Spermophilinus molars is well known and, thus, deserves no detailed description. We only notice that the parastyle is not significantly developed in the P4. P4-M3 have a strong, crest-shaped mesostyle. It forms a bridge between the paracone and metacone $(\mathrm{P} 4)$, or is directed rather towards the labial part of the tooth (M1, M2). The crest is observed in the M3, but included in the expanded posterior part of the tooth. The M1 differs from M2 by the metacone which is more clearly labially differentiated, the protocone which has a more central position, as well as the less well-achieved metalophid/protocone junction.

NMA-2019-2/2352. The specimen shows less trace of tooth wear. The P4 has a parastyle completely included in the anteroloph. The P3 is complete, uniradicular, posteriorly directed, and placed between the anterolabial root and lingual root of the P4. The crown of the tooth is conical and comes into contact with the $\mathrm{P} 4$ under the hypothetical parastyle.

Remarks. The molars show the characteristics of Spermophilinus, a genus relatively common in the German middle Miocene (see details in Ziegler 2005, for instance). To be brief, four known species of Spermophilinus (S. besana, $S$. bredai, S. turolensis and S. giganteus) differ essentially in size. It has long been accepted that these species represent a lineage characterized by an increase in molar size. Bosma et al. (2018) have recently changed this view by demonstrating the presence of two coexisting species of Spermophilinus in a single site in Anatolia. It is out of the scope of this paper to review the German record in order to discuss the specific homogeneity, and we, thus, consider the Bavarian fossil populations to be monospecific in each locality.

The early and middle Miocene Spermophilinus collections from the Upper Freshwater Molasse were considered to be assigned to $S$. aff. bredai for the older localities while $S$. bredai is found in younger ones (e.g., Ziegler and Fahlbusch 1986, Kälin 1993). Ziegler (2005; following de 
Bruijn 1995) considered that the smaller and older species belong to $S$. besana. The measurements of M1 and M2 from selected localities in Switzerland and southern Germany are shown in the Text-fig. 3. It emerges that it becomes difficult to clearly separate the species in a stratigraphic framework. The use of the average tooth size for all selected localities would certainly have added more clarity to present the evolution of the genus, but would not have allowed us to discuss in detail the size of our specimens (some molar samples are indeed too small). Pending further study of the Petersbuch 136 material, the studied specimens do not oppose a taxonomic assignment to $S$. bredai.

It is important to note for the following discussion that we consider the tooth shown in Text-fig. 2 as a P3 and not as a DP3 that has not been replaced.

\section{Discussion}

The P3 of extant sciurids is generally reduced to a small conical tooth, although there are representatives with a more molariform P3, while in others the premolar is absent. The nature of the fossil record implies that this tooth is poorly documented, and rarely found in situ. Data of Spermophilinus collected in the literature are limited to a handful of specimens: 1) Ginsburg and Mein (2012) report a maxillary from Sansan (France) that still have the P3-M2 (P3 has not been described nor figured). 2) A P3 in situ has been recorded in a specimen from Höll (Germany; Prieto et al. 2017). This tooth is very simple, single-rooted, with a round crown in occlusal view. 3) Bosma et al. (2018) report an isolated P3 in Yenieskihisar (Turkey). The premolar, probably attributable to $S$. besana, has the shape of a truncated cone.

The P3 can be relatively large and important for biostratigraphic purposes. This has been shown in the Pleistocene Spermophilus praecox-S. nogaici lineage in Eastern Europe where the tooth increases in size and changes morphology during its evolution (Sinitsa and Pogodina 2019). Spermophilinus from Petersbuch 136 can be only compared with the material from Höll. The premolar

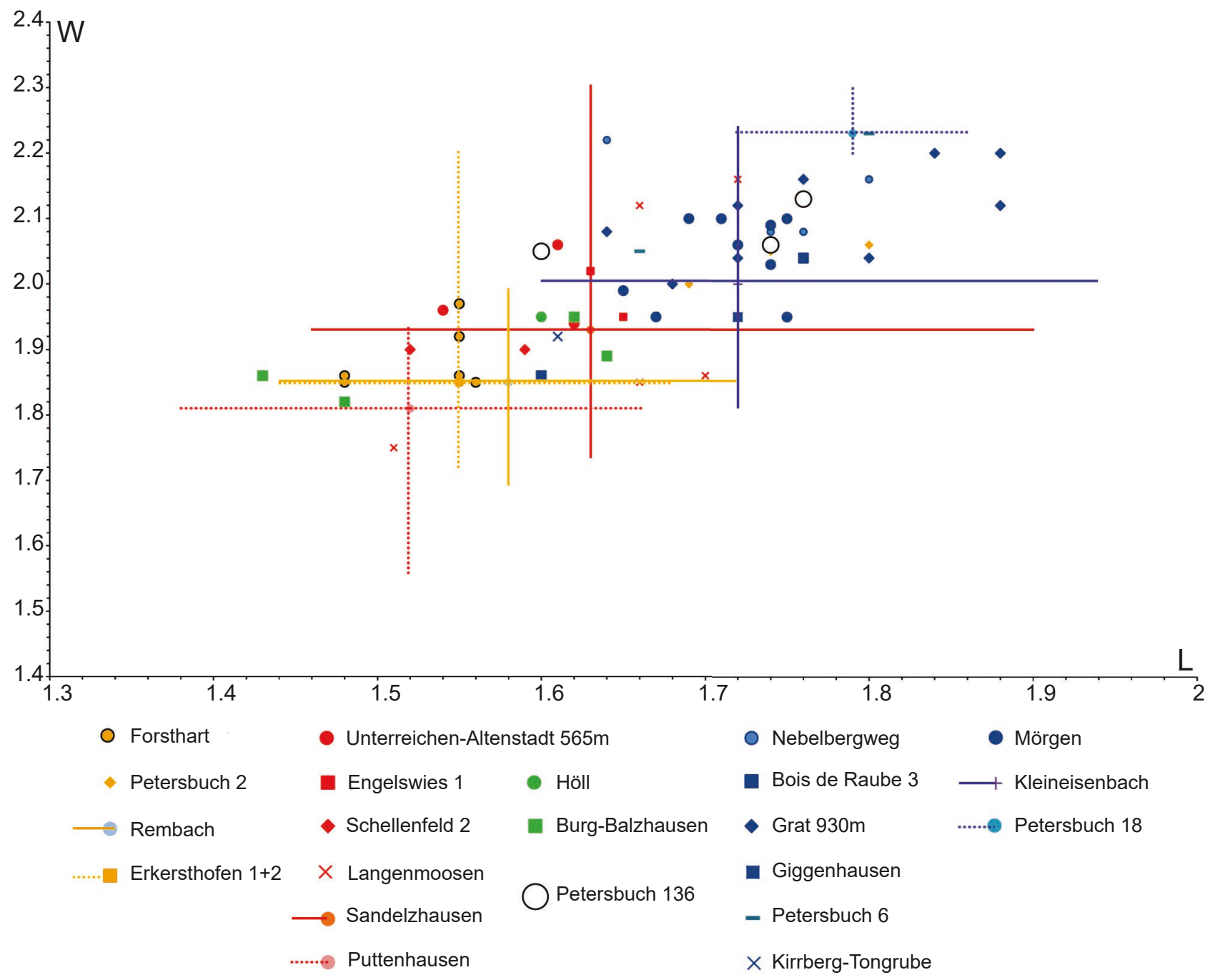

Text-fig. 3. Scatter diagram of mean L/W values of selected Spermophilinus upper first molars (M1 and M2) from Switzerland and south Germany. The crosses correspond to the minimum and maximum values of the length and width. The intersection gives the value of the mean. Comparative data are after Ziegler and Fahlbusch (1986), Bolliger (1992), Kälin (1993), Ziegler (1995, 2005), Kälin and Engesser (2001), Prieto (2007), Prieto et al. (2009, 2017), Seehuber (2009). Blue: localities younger than 14 Ma (S. bredai); Green: localities ranging from $\sim 14$ Ma to 15Ma (S. bredai); Red: localities ranging from $\sim 15$ Ma to $\sim 16$ Ma (S. besana); Yellow: older localities (most S. besana). 
Table 1. Dental anomalies affecting Sciuridae (from literature).

\begin{tabular}{|l|l|l|l|l|}
\hline \multicolumn{1}{|c|}{ Taxon } & \multicolumn{1}{|c|}{ Anomaly } & Tooth position & \multicolumn{1}{c|}{ Dating } & \multicolumn{1}{c|}{ Reference } \\
\hline Petaurista sp. & Rotation & $\mathrm{P} 4$ & recent & Miles and Grigson 2003 \\
\hline Marmota bobak & Rotation & $\mathrm{P} 3$ & recent & Miles and Grigson 2003 \\
\hline Marmota caligata + M. monax + M. broweri & Supernumerary teeth & $\mathrm{p} 4$ and M1 & recent & Winer et al. 2016 \\
\hline Spermophilus richardsonii complex & Supernumerary teeth & distal upper M & Pleistocene & Goodwin 1998 \\
\hline Spermophilus richardsonii complex & Supernumerary teeth & distal upper M & recent & Goodwin 1998 \\
\hline Sciurus vulgaris & Supernumerary teeth & distal upper M & recent & Mein 1986 \\
\hline Eutamias sibiricus & Missing tooth & P3 & recent & Jones 1960, Jones and Johnson 1965 \\
\hline Heteroxerus grivensis & Different shape/morphology & m3 and M3 & Miocene & Mein 1986 \\
\hline Sciurus lis & Missing tooth & P3 & recent & Miyao 1971 \\
\hline Sciuridae indet. & Different shape/morphology & P4 & Miocene & Mein 1986 \\
\hline Paraxerus cepapi & Missing tooth in older animals & premolar & recent & Viljoen 1977 \\
\hline
\end{tabular}

from the Molasse is slightly larger (Di: minimum: $0.52 \mathrm{~mm}$, maximum: $0.63 \mathrm{~mm}$ ). It is implanted in the same way as in Petersbuch, i.e., it develops along the anterior root of the P4 (which is absent in Höll) and is placed anterolingually from this root.

Dental anomalies have rarely been studied in Sciuridae. In Table 1, we have summarised some cases listed in the literature. In P3, the most common anomaly, namely the missing of the premolar, has been recorded in the Siberian chipmunk (e.g., Jones 1960) or the Japanese squirrel (Miyao 1971). When Miles and Grigson (2003) recognized certain variability in the position of the premolar, they figured (Miles and Grigson 2003: fig. 14.1) a rotated tooth with "buccal surface turned mesially and misplaced slightly lingually".

The maxillary from Petersbuch is thus exceptional in its rarity. The origin of the three roots remains mysterious:

1) It is unlikely that these three roots derive from the DP4 because of their size and position, all anterior to P4.
Text-fig. 4 clearly shows that only the anterior root of the DP4 could be in the front position of the P4.

2) The arrangement and size of the roots resemble the P4, where the lingual root is the strongest. It could be supposed that an aberrant triradicular P3 has lost its crown during its eruption due to lack of sufficient space. This hypothesis is not very credible because it would imply an aberrant molariform P3.

3) The third hypothesis refers to the existence of a hyperdontia phenomenon. This phenomenon, nevertheless, has never been described for premolar elements in sciurids. The few examples published about hyperdontia in squirrels most often described the presence of extra teeth at the distal end of the upper or lower tooth rows (Mein 1986, Goodwin 1998). However, Winer et al. (2017: fig. 2) presented a hoary marmot mandible with additional premolars. Three (or four?) small teeth, apparently uniradicular, develop around the $\mathrm{p} 4$.

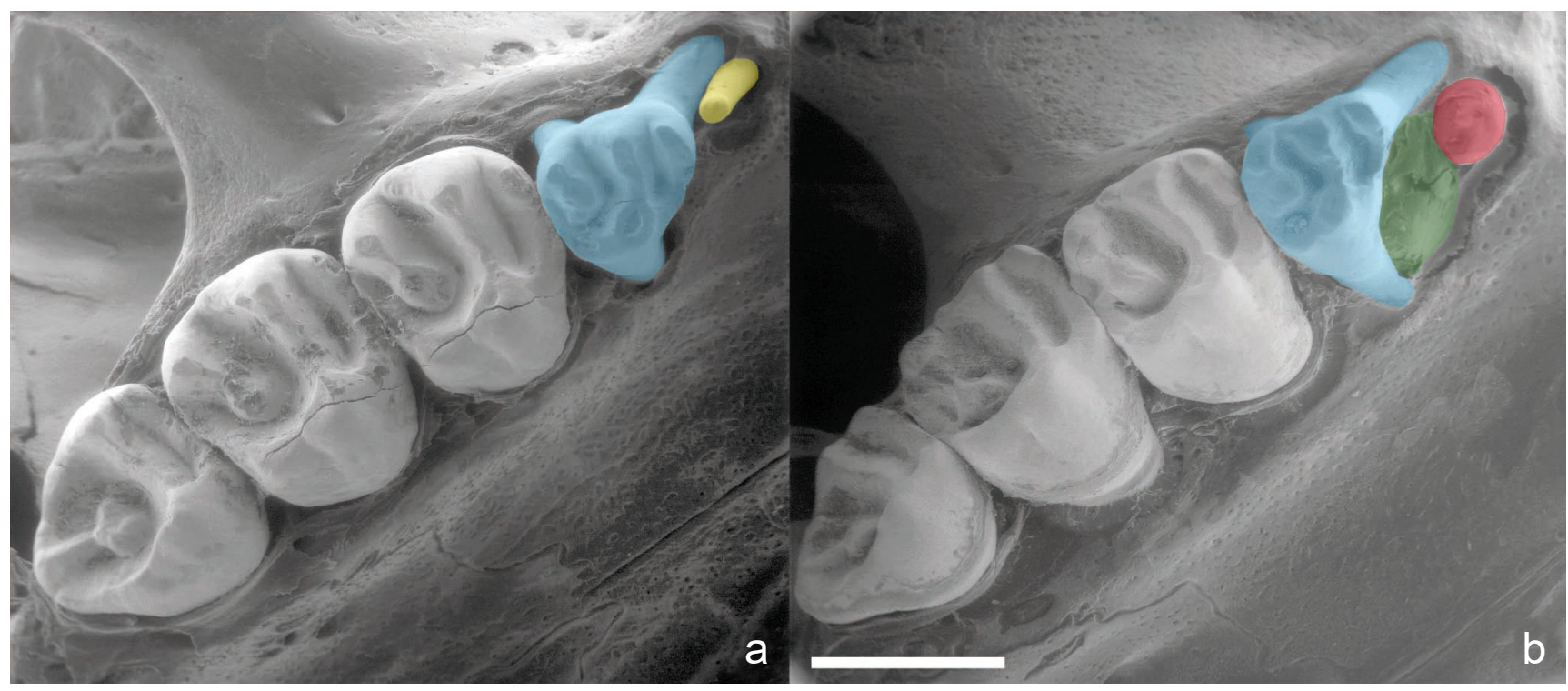

Text-fig. 4. Tooth replacement by the barbary ground squirrel (Atlantoxerus getulus). a - right maxillary with DP3-M3 (MNCN5522) showing the relative position of the two deciduous teeth; b - right maxillary with P3-M3 (MNCN-5538) showing the replacement of the DP4 by the P4 (not erupted). Blue: DP4; green: P4; yellow DP3; red: P3. 
Therefore, in our specimen, the presence of three roots anterior to the P4 cannot be explained if they belong to a single dental element, and so we have to hypothesize that they might correspond to roots from different ones.

4) It could be that the small labial root corresponds to that of a small DP3 like in Atlantoxerus or Ammospermophilus and the other two roots to a biradiculated P3. A biradiculated P3 represents an aberration, since in most of the sciurids having P3 this element possesses only a single root, as in the other Spermophilinus specimen described here. In this case, P3 would maintain a position similar to that observed at Petersbuch and Höll.

5) It is also possible that the roots belong to three different elements, i.e., to DP3, DP4 and P3. In this case, the labial root must be a remnant of the labial root of the DP4 because of its anterolabial position in relation to the other elements. The middle root would correspond to the one of the P3 because it is better developed than the lingual one and close to the position expected for the P3. The lingual root would correspond to the DP3. The assignments of DP3 and P3 could also be reversed. However, this will imply that both deciduous and adult third premolars could have been functional in Spermophilinus due to the important development of their respective roots. Wood (1969) reported the presence of functional DP3 in Marmota and Otospermophilus. The DP3 is also recognized in the fossil record of ?Spermophilus craigini from the Pliocene/ Pleistocene transition of USA (Goodwin and Hayes 1994). One could imagine that the milk tooth was not removed during the dental replacement process in the individual NMA-2019-1/2352 from Petersbuch 136.

We propose to retain proposal 3) and 5), namely hyperdontia and conservation of the roots of three different teeth, as the most likely scenarios, although we cannot definitively conclude based on this single specimen.

\section{Conclusions}

The maxillary presented in this work is the oldest evidence of dental anomaly in sciurids (see Tab. 1), Heteroxerus grivensis from La Grive L7 being slightly younger than the specimen from Petersbuch 136. The aberrant morphology, probably hyperdontia or no replacement of tooth elements, affects the area of the P3, a tooth that is generally not well documented in the fossil record. Petersbuch 136 yielded an extensive fauna and it is very likely that an important collection of jaws and mandibles can be made available to science in the future. It will then be interesting to study the frequency and nature of the anomalies encountered in a population of Spermophilinus in the German middle Miocene.

\section{Acknowledgements}

We thank the editors of the volume in memoriam for Dr. G. Storch for the invitation to participate. Lutz Maul (guest editor, Weimar), Lilia Popova (Kiev), an anonymous reviewer as well as an editor Jan Wagner enhanced this work through their comments.

\section{References}

Bolliger, T. (1992): Kleinsäuger aus der Miozänmolasse der Ostschweiz. - Documenta naturae, 75: 1-297.

Bosma, A. A., Bruijn, H. de, Wessels, W. (2018): Early and middle Miocene Sciuridae (Mammalia, Rodentia) from Anatolia, Turkey. - Journal of Vertebrate Paleontology, 38(6): e1537281 (25 pp.). https://doi.org/10.1080/02724634.2018.1537281

Bruijn, H. de (1995): The Vertebrate Locality Maramena (Macedonia, Greece) at the Turolian-Ruscinian Boundary (Neogene) 8. Sciuridae, Petauristidae and Eomyidae (Rodentia, Mammalia). - Münchner Geowissenschaftliche Abhandlungen, A, 28: 87-102.

Bruijn, H. de, Bosma, A.A. (2012): Spermophilinus and Csakvaromys, two names for the same genus of ground squirrel (Tamiini, Sciuridae, Rodentia, Mammalia) from the Neogene of Europe. - Annalen des Naturhistorischen Museums in Wien, A, 114: 317-320.

Casanovas-Vilar, I., Almécija, S., Alba, D. (2015): Late Miocene flying squirrels from Can Llobateres 1 (Vallès-Penedès Basin, Catalonia): systematics and palaeobiogeography. Palaeobiodiversity and Palaeo-environments, 95: 353-372. https://doi.org/10.1007/s12549-015-0192-1

Charles, C., Viriot, L. (2015): Variations and anomalies in rodent teeth and their importance for testing computational models of development. - In: Cox, P. G., Hautier, L. (eds), Evolution of the Rodents: Advances in Phylogeny, Functional Morphology and Development. Cambridge University Press, Cambridge, pp. 405-423. https://doi.org/10.1017/CBO9781107360150.016

Ginsburg, L., Mein, P., (2012): Les Sciuridae (Rodentia) de Sansan. - In: Peigné, S., Sen, S. (eds), Mammifères de Sansan. Mémoires du Muséum national d'Histoire naturelle, Paris, 203: 81-94.

Goodwin, H. T. (1998): Supernumerary teeth in Pleistocene, recent and hybrid individuals of the Spermophilus richardsonii complex (Sciuridae). - Journal of Mammalogy, 79: 1161-1169. https://doi.org/10.2307/1383007

Goodwin, H. T., Hayes, F. H. (1994): Morphologically derived ground squirrels from the Borchers local fauna, Meade county, Kansas, with a redescription of ?Spermophilus cragini. - Journal of Vertebrate Paleontology, 14(2): 278-291. https://doi.org/10.1080/02724634.1994.10011557

Imai, D., Pesapane, R., Conroy, C. J., Alarcón, C. N., Alla, N., Okino, R. A., Fung, J., Murphy, B. G., Verstraete, F. J. M., Foley, J. E. (2018): Apical Elongation of Molar Teeth in Captive Microtus Voles. - Veterinary Pathology, 55: 572-583. https://doi.org/10.1177/0300985818758469

Jehon, A. H., Prochazkova, M., Sherman, M., Manoli, D. S., Shah, N. M., Carbone, L., Klein, O. (2015): Spontaneous emergence of overgrown molar teeth in a colony of Prairie voles (Microtus ochrogaster). - International Journal of Oral Science, 7: 23-26. https://doi.org/10.1038/ijos.2014.75

Jones, J. K. (1960): Absence of third upper premolar in Eutamias. - Journal of Mammalogy, 41: 268-269. https://doi.org/10.2307/1376369 
Jones, J. K., Johnson, D. H. (1965): Synopsis of the lagomorphs and rodents of Korea. - University of Kansas Publications, Museum of Natural History, 16: 357-407.

Kälin, D. (1993): Stratigraphie und Säugetierfaunen der oberen Süßwassermolasse der Nordwestschweiz; PhD Thesis - MS, Eidgenössische Technische Hochschule Zürich, Zürich, Swittzerland, 238 pp. (copy in Bibliothek Erdwissenschaften, ETH Zürich)

Kälin, D., Engesser, B. (2001): Die jungmiozäne Säugetierfauna vom Nebelbergweg bei Nunningen (Kanton Solothurn, Schweiz). - Schweizerische Paläontologische Abhandlungen, 121: 1-61.

Kretzoi, M., Fejfar, O. (2005): Sciurids and Cricetids (Mammalia, Rodentia) from Rudabánya. Palaeontographia Italica, 90: 113-148.

Mein, P. (1986): Quelques dents fossiles de morphologie abberrante. - In: Russel, D. E., Santoro, J.-P., SigogneauRussel, D. (eds), Teeth Revisited: Proceedings of the VIIth International Symposium on Dental Morphology, Paris 1986. Mémoires du Muséum d'Histoire naturelle de Paris, Série C, 53: 277-284.

Miles, A. E. W., Grigson, C. (eds) (2003): Colyer's Variations and Diseases of the Teeth of Animals. - Cambridge University Press, Cambridge, 692 pp.

Miyao, T. (1971): Absence of the third upper premolar and the order of the eruption of the cheek teeth in Sciurus lis. - Journal of the Mammalogical Society of Japan, 5: 142-143. (in Japanese with English abstract)

Prieto, J. (2007): Kleinsäuger-Biostratigraphie und Paläoökologie des höheren Mittelmiozäns (MN 8) Bayerns: Spaltenfüllungen der Fränkischen Alb und Lokalitäten der Oberen Süßwassermolasse im Vergleich; Dissertation [PhD Thesis]. - MS, Ludwig Maximilians Universität München, Munich, Germany, 213 pp. (copy in private library of JP)

Prieto, J., Böhme, M., Maurer, H., Heissig, K., Abdul Aziz, H. (2009): Biostratigraphy and sedimentology of the Fluviatile Untere Serie (Early and Middle Miocene) in the central part of the North Alpine Foreland Basin: implications for palaeoenvironment and climate. International Journal of Earth Sciences (Geologische Rundschau), 98: 1767-1791.

https://doi.org/10.1007/s00531-008-0331-2
Prieto, J., Peláez-Campomanes, P., Scholz, H. (2017): Sciurids (Rodentia, Mammalia) from Höll (Middle Miocene, Bavaria). - Zitteliana, A, 89: 351-354.

Prieto, J., Rummel, M. (2016): Some considerations about the small-mammal evolution in South Germany, with emphasis on late Burdigalian-earliest Tortonian (Miocene) cricetid rodents. - Comptes Rendus Palevol, 15: 837-854. https://doi.org/10.1016/j.crpv.2016.08.002

Seehuber, U. (2009): Litho- und biostratigraphische Untersuchungen in der Oberen Süßwassermolasse in der Umgebung von Kirschheim in Schwaben. - Documenta naturae, 175: 1-355.

Sinitsa, M. B., Pogodina, N. V. (2019): The evolution of early Spermophilus in eastern Europe and the antiquity of the Old World ground squirrels. - Acta Palaeontologica Polonica, 64: 643-667. https://doi.org/10.4202/app.00605.2019

Viljoen, S. (1977): Age Determination in the Bush Squirrel, Paraxerus cepapi cepapi. - Zoologica Africana, 12(1): 89-99. https://doi.org/10.1080/00445096.1977.11447551

Winer, J. N., Arzi, B., Leale, D. M., Verstraete, F. J. M. (2017): Dental Pathology of the Hoary Marmot (Marmota caligata), Groundhog (Marmota monax) and Alaska Marmot (Marmota broweri). - Journal of Comparative Pathology, 156(1): 42-52. https://doi.org/10.1016/j.jcpa.2016.10.005

Wood, A. E. (1969): The Third Upper Premolars of the Woodchuck (Marmota). - Journal of Mammalogy, 50(3): 608-609. https://doi.org/10.2307/1378787

Ziegler, R. (1995): Die untermiozänen Kleinsäugerfaunen aus den Süßwasserkalken von Engelswies und Schellenfeld bei Sigmarigen (Baden-Württenberg). - Stuttgarter Beiträge zur Naturkunde, Serie B, 228: 1-53.

Ziegler, R. (2005): The squirrels (Sciuridae, Mammalia) of the Miocene Fossil-Lagerstaette Sandelzhausen (Bavaria, S Germany). - Neues Jahrbuch für Geologie und Paläontologie, Abhandlungen, 237: 273-312. https://doi.org/10.1127/njgpa/237/2005/273

Ziegler, R., Fahlbusch, V. (1986): Kleinsäuger-Faunen aus der basalen Oberen Süßwasser-Molasse Niederbayerns. Zitteliana, A, 14: 3-58. 